\title{
JAN ROMEIN IN SUID-AFRIKA.
}

Die afgelope dekade of so was ons Afrikaansprekende historici aan die verskillende universiteite van ons land stilweg besig om elkeen vir homself rekenskap te gee van die eise wat sy wetenskap aan hom stel. Navorsing is in die verskillende argiewe van ons land gedoen en het daar geleidelik interessante en belangrike werke die lig gesien. Omdat die eise wat die historiese wetenskap stel so hoog is en omdat die daarstelling van ' $n$ historiese beeld diepgaande en onselfsugtige navorsing van die eerlike historikus verg, is dit ook te verstane dat die gelewerde produkte langsaam gekom het, maar uiteindelik het historici soos prof. Thom, dr. P. J. van der Merwe, prof. Leo Fouche, dr. C. Beyers, prof. Uys, prof. S. P. Engelbrecht, prof. A. N. Pelzer, dr. F. du Toit Spies, dr. G. D. Scholtz en andere elk op sy eie gebied besondere verdienstelike en hoogstaande werk gelewer. Die politieke, godsdienstige, ekonomiesstaatkundige en kultuurgrondslae van ons volk se wordingsgeskiedenis is nagegaan en daarvan rekenskap gegee') sodat, ofskoon daar nog veel gedoen kan word, die verledebeeld van ons volk se wording taamlik duidelik daargestel is.

Gedurige kontak is met Europa gehandhaaf sodat enige vordering wat in Europa gemaak is, nie aan ons verby gegaan het nie. Manne soos Herder, Hegel, Ranke, Macaulay, Greene, Geyl, Romein, Troeltch en die menige ander grondleggers en uitbouers en steeds werksame historici en denkers, was en is vir ons historici geen onbekendes nie. Wat die groot denkers van Europa, Amerika en selfs Asië oor die vak te sê gehad het of het, is deur die verskillende professore en lektore aan die universiteite van Kaapstad, Stellenbosch, Grahamstad, Bloemfontein, Pietermaritsburg, Potchefstroom en Pretoria met al hul implikasies en vorderinge aan die studente oorgedra in 'n waaragtige poging om ook hier in Suid-Afrika die fondamente te lê van 'n wetenskap wat in Europa sulke diep spore nagelaat het.

1) As voorbeeld kan die volgende werke hier genoem word :-

Arndt, Dr. E. H. D.: Banking and Currency Development in South Africa.

Beyers, Dr. Coenraad: Die Kaapse Patriotte, 1779-1791 (1929).

Botha, Dr. Philip R.: Die Staatkundige Ontwikkeling van die SuidAfrikaanse Republiek onder Kruger en Leyds (1926).

Dreyer, A. : Die Kaapse Kerk en die Groot Trek (1929).

Breytenbach, J. H.: Die Tweede Vryheidsoorlog (1948).

Engelbrecht, S. P.: Geskiedenis van die Nederduits Hervormde Kerk van Afrika $(1920,1925,1936)$.

Engelbrecht, S. P.: Thomas François Burgers (1933).

Leyds, W. J.: de Eerste Annexatie van de Transvaal (1908).

Leyds, W. J.: Het Insluiten van de Boeren-Republieken (1914).

Pelzer, A. N.: Wordingsjare (1950).

Thom, H. B.: Die Lewe van Gert Maritz (1947).

Van der Merwe, P. J.: Die Trekboer in die Geskiedenis van die Kaapkolonie (1938). 
In 1944 is hierdie werksaamhede versteur deur dr. J. S. Merais wat met sy sogenaamde liberale standpunt 'n opspraakwekkende werkie die lig laat sien het. ${ }^{2}$ ) Marais se werkie was egter so ooglopend eensydig en bevooroordeeld ${ }^{3}$ ) dat die tydelike furore wat dit veroorsaak het weldra bedaar het. Wydlopend kon die invloed daarvan nie wees nie, eenvoudig omdat enige historikus wat hom maar enigsins tot 'n mate vergewis het van sy taak weldra besef het dat hierdie werkie nie aan die eise van die geskiedeniswetenskap voldoen nie.

Die afgelope twee jaar het die reeds bekende Nederlandse historikus Jan Romein onverwags sensasionele waarde by ons gekry. Leerlinge van hom het terug gekom na Suid-Afrika toe en wat hulle oor hom te sê gehad het en oor die toepassing van sy idees op die historiese wetenskap, het daartoe aanleiding gegee dat die verskillende historici, in stede daarvan om Jan Romein as historiese denker en wetenskaplike na meriete te beoordeel en in te pas by die ander denkers oor die onderwerp en verder sy veronderstellinge te gebruik saam met die ander en te toets aan die eise wat ons wetenskap aan ons stel, is Jan Romein mee gepolemiseer en mee gedweep. Kant is gekies teenoor mekaar en sulke ontstellend-vérreikende gevolge het dit reeds gehad dat ons kerke ook daarby betrokke geraak het. ${ }^{4}$ )

Weliswaar het Jan Romein se naam, teen die tyd dat die polemiek die kerke bereik het, of teen die tyd dat sekere daarna gegryp het, nie meer opgeduik nie, maar soos ons in wat sal volg sal sien, het sy geskiedenisstandpunt wat voorgehou is, die modus operandi geword waardeur ou geskille weer opgerakel is. Ook is, soos sal blyk, 'n poging aangewend om 'n paar historici wat oor sekere aspekte van die Transvaalse geskiedenis navorsing gedoen het, af te hok van die res van ons Afrikaanse historici en word hulle onvleiend bestempel as behorende tot die „Noordelike skool"s). Word daar verder beweer dat hulle "klakkelose" navolgers is van die kerkhistorikus S. P. Engelbrecht $^{6}$ ) en word hul navorsingswerk of verswyg of eensydig en sonder enige poging tot insig veroordeel. ${ }^{7}$ )

2) Marais, J. S. : Maynier and the first Boer Republic (1944).

3) Vgl. van Rooyen, T. S. en Eloff, J. F.: Memorandum: 'n Historiese oorsig oor die Inbesitname van Gronde deur verskillende Bevolkingsgroepe in Suid-Afrika (uitgesonderd Kleurlinge en Indiërs) (Tomlinsonkommissie).

4) Die Voorligter, April 1953.

Die Hervormer, Maart 1953.

Die Kerkbode, 15 April 1953.

3) Die Voorligter, April 1953.

6) Tbid.

i) Byvoorbeeld Dr. G. D. Scholtz, Vgl. Die Transvaler van 5 Maart 1952. Dr. Scholtz kan gerus eers 'n beter studie maak van die stamnaturel voordat hy uitspraak lewer oor hulle. Vgl. „Bijdragen voor de Geschiedenis der Nederlanden", deel VII. Om die naturel te gaan beskou as 'n barbaar sonder enige stampatriotisme, maak nie alleen die antropologie 'n klug nie, maar ook die idee van apartheid. 


\section{Jan Romein.--Die Grondslae van sy Denke.}

Dit het dus tyd geword om die hele sogenaamde polemiek sover moontlik samevattend te behandel sodat ons historici weer kan terugkeer tot die werklikheid en die ongesonde gees van onverantwoordelike polemiek uit ons kerke geweer kan word.

Jan Romein is in 1893 gebore, sodat hy 'n tydgenoot geword het van die ontstellende gebeurtenisse wat die Europese mens gedurende die daaropvolgende vyftig jaar vasgevang het en uitgeloop het op die vernietigende oorloë van 1914-18 en 1939-45. Dit was ook die tydperk van die selfbewuswording van die proletariërmassas wat gekulmineer het in die Marxisties-kommunistiese rewolusie in Rusland tydens en net na die eerste wêreldoorlog.

Vir die van ons wat die geskiedenis ken, is dit duidelik dat hierdie bloedige botsings en rewolusionêre tydperke in Europa ook in der waarheid botsings was tussen die nasionale aspirasies van die Europese volkere en ook uitinge was van botsende waardestellinge. Veral na 1848 het die Europese mens sterk bewus geword van die eie nasie en die uitlewing van daardie nasionalisme binne sowel as buite sy eie landsgrense. Dit het meegebring die nasionale imperialistiese oorloë tussen Duitsland (Pruise) en Oostenryk, Duitsland en Frankryk en uiteindelik Duitsland en Oostenryk teen Engeland, Rusland, Frankryk en die res van Europa en Asië.

1848 was egter ook die verskyningsjaar van die deur Marx en Engels opgestelde kommunistiese manifes wat uitloop op die militarisering van die werkersklasse in Europa met sy kulminasie in die Russiese rewolusie onder Lenin en Trotsky en soos voortgesit deur Stalin.

Vanselfsprekend is die eng-nasionale as waardebeginsel deur die verskillende nasies benadruk en is daar in die nasionale verlede inspirasie gesoek wat moes dien as stukrag agter die uitinge en strewe van die nasie. ${ }^{8}$ ) Daarlangs het egter ontstaan die utopiese ideaal van Marx en Engels van ' $n$ internasionale ontwaking van die proletariërs. Die kommunisme is gesien as ' $n$ sintese en dus antitetiese uiting of resultaat van die kapitalistiese stelsel. Hierdeur sluit hulle nou aan by die Duitse filosoof Hegel.9) En omdat hierdie beginsel beskou is as voorkomend by alle beskaafde volkere en ook omdat geglo is dat die onderdrukte werkersklas ' $n$ universele verskynsel is, word an die kommunistiese leerstelling en beweging 'n internasionale politieke doel gestel. Die Marxisme ontken egter nie die werklikheid van die verskynsel soos voorkomend in 'n nasie nie, maar bo en buite die nasie word die beginsel van die dialektiese werklikheid met as verkristalliseerde internasionale proletariaat as 'n onvermydelike gesien. ${ }^{10}$ )

8) Byv. by die Duitse historikus Treitschke.

) Löwith, K. : Von Hegel zu Nietsche. Der revolutionare Bruch im Denken des 19. Jahrhunderts. pp. 44-118.

10) Nicholson, J. S.: The Revival of Marxism. (London. 1921). 
Ook Jan Romein, as in tyd en ruimte gebonde individu, moes noodwendig vasgevang word binne die verskynsels van sy tyd. As historikus aanvaar hy die Hegelse dialektiek en sien hy die historiese voortgang as die ontwikkeling van 'n sinteseverskynsel van binne 'n antitetiese toestand. ${ }^{11}$ ) Tese-toestand word deur Marx as die urkommunisme daargestel ('n op kommunaal-berustende gemeenskap). Daaruit ontwikkel die eie-belang van die indiwidu met sy kapitalistiese klasseverskynsel, maar juis omdat die kapitalisme is wat dit is, vind ons binne die kapitalistiese gemeenskap aanwesig die verdrukte en verontregte werkersklas wat geleidelik aangroei totdat hulle die mag kan oorneem; soos dit gebeur het in Rusland. Hierdie proletariaat is uiteraard anti-individualisties, 'n massaverskynsel en is sy uiting ook 'n nie-individuele op die massa berustende monumentale beskawingskultuur. Alles moet groots wees en tot die massa spreek. ${ }^{12}$ ) Dit verwerp ook die nie-sigbare, die ideële ${ }^{13}$ ) of godsdienstige soos ons westerlinge byvoorbeeld die Christelike leer verstaan ${ }^{1-4}$ ) en stel in die plek daarvan dit wat die massagroep as magsgroep homself sal laat handhaaf; byvoorbeeld die masjien. ${ }^{15}$ )

Jan Romein lewe dus in 'n tydperk waarin waardebeginsels of die dinge waaraan groepe mense glo en wat vir hulle as lewensbelangrik voorkom, veranderinge ondergaan. Die mens kan dus (volgens Romein) nie aan ' $n$ waardebeginsel of dit wat vir hom as waarheid voorkom, as 'n absolute konstante dink nie. Inteendeel, uit die verloop van die menslike geskiedenis is dit maar al te duidelik dat die mens se siening van die dinge om hom gedurig verander het.

Die mens vind hom binne 'n omgewing. Hy is omgewingsgebonde, maar die mens gryp in op die omgewing soos hy dit op daardie moment begryp. Die menslike gees, om saam met Exner te praat, is op so ' $n$ wyse gekonstrueer dat hy in staat is om op min of meer adekwate wyse te kan konstrueer wat daar om hom in die werklikheid gebeur. Die mens probeer dus om die werklikheid te formuleer in die vorm van „natuurwette". Maar omdat die menslike denke nie 'n kon. stante waarde-element inhou nie maar veranderbaar is, is die natuurwette wat hy daarstel ook nie konstant nie en is aan verandering of uitbouing onderhewig. Die natuurwette bestaan dus nie as 'n absolute verskynsel nie maar is onderhewig aan die veranderbare werklikheidsiening van die mens. ${ }^{16}$ )

As dialektiese denker word Romein dus ook verplig om die geldigheid van die verandering van die waardestandpunt van die mens in die

11) Romein, J. : Het Onvoltooid Verleden, p. 18 (1948).

12) Ibid. p. 329.: Monumentalisme en Machinisme.

18) Ibid.

14) Hindus, M. : Humanity Uprooted, pp. 21-38.

15) Romein, J.: Het Onvoltooid Verleden, pp. 329-340.

16) Romein, J.: Tussen Vrees en Vrijheid, p. 66 (1950). 
tydsverloop te toets. Die mens en die historikus-as-mens is binne die eie tyd en omgewing gebonde en dit is binne hierdie tydsgebondenheid wat hy ook die materiaal vind vir die studie van sy onderwerp. ${ }^{17}$ ) Met ander woorde, soos hy dit self uitdruk: „De tijd werpt de problemen op : de wetenschap grijpt ze aan en heeft, als zij ware wetenschap is, het geduld om het resultaat met belangstelling af te wachten. Desnoods al ondergaande". ${ }^{18}$ )

Die mens, dus vasgevang binne 'n tyd-en ruimte-omgewing wat deur die mens-in-die-geheel- of massa tot stand gebring is met 'n eie verantwoordingdoende in die tydsverloop veranderde wetmatigheid en waardebepaling (Wertidee), kan ook noodwendig nie anders as om die historiese verlede soos dit spreek tot die hedemens in 'n gedurig veranderde verband te sien nie. Die verledebeeld wat deur die historikus op bronne berustende studie daargestel word, is dus ook nie ' $n$ absolute konstante beeld nie, maar gedurig veranderend. Die mens wil homself, die toestand en omstandighede waarin hy hom bevind na aanleiding van sy verlede, verklaar, maar instede daarvan om dit te doen word die verledebeeld daargestel uit hoofde en kragtens die hede. Dit verklaar ook waarom die ",sien" van die middeleeue, van die Romeinse Ryk en die vraagstukke wat daaruit voortvloei soos wanneer die Romeinse Ryk tot 'n val gekom het, die invloed van die Christendom op die Romeinse Ryk, die sogenaamde voortsetting van die Romeinse Ryk in die Heilige Romeinse Ryk, die aanvang van die Renaissance, die Renaissance as beskawingsverskynsel ens. so verskillend is by die verskillende historici. ${ }^{19}$ )

Dus omdat die historiograaf gebonde is aan sy tyd en omgewing, is daar ' $n$ duidelike verband tussen sy interpretasie en historiese begrip en tussen laasgenoemde en die wêreldbeskouing van die geskiedskrywer. Daarom weerspieël die historiograaf se werk sy tydsomstandigheid., of die besondere historiese moment waarin hy hom bevind. ${ }^{20}$ ) Dit is dus ook moontlik om na aanleiding van die in tydgebonde uitinge van die mens in die vorm van pamflette, memoirs, vlugskrifte, ens. ' $n$ historiese beeld te skep van daardie besondere tyd. ${ }^{21}$ ) Ook is dit vir die historikus veroorloof om die feitemateriaal van die verlede wat as chaotiese reste daargelaat is, te toets aan die deur die omgewing opgedronge lewensbeskouing en as die materiaal sinvol beantwoord aan die vooropgestelde teo-ie, dan mag die materiaal gebruik word vir die daarstelling en uitwerking van die teorie. Romein erken

17) Ibid. p. 38 .

18) Ibid. p. 47.

19) Romein, J.: Het Onvoltooid Verleden, hoofstukke 3, 4, 5, 6, 7, pp. 111209.

so) Dr. Hugo, M.: Jan Romein. Die Nederlandse Teoretiese Historikus. Uit.: Tydskrif vir Wetenskap en Kuns, deel XI, April 1951.

21) Soos gedoen deur dr. P. de Vries. 'n Leerling van Romein. „Het beeld van Lodewijk XIV in de Franse geschiedschrijving"-, 1947. 
dat 'n teorie buite die werklikheid, getoets aan die materiaal uit die verlede, 'n valse werklikheid openbaar, maar gewoonlik en dus by wetenskaplike denkers, is daar altoos 'n element van die werklikheid aanwesig. ${ }^{22}$ ) Of anders gestel: 'n Teorie is 'n uit ervaring afgeleide stenogram van 'n gedeelte van die werklikheid. ${ }^{23}$ ) Dit gee dus nooit die werklikheid in haar volheid weer nie, maar net ' $n$ afskynsel dus daarvan. ${ }^{24}$ )

Maar die werklikheid self is, volgens die Hegelse dialektiek, nie 'n absolute werklikheid nie, dit bly relatief omdat daar reeds 'n voortskrydende, uit die werklikheidsmassa losmakende antitetiese element in aanwesig is wat vir daardie werklikheidsmoment as niebrstaande onbelangrike verskynsel voorkom. ${ }^{25}$ )

'n Poging om die verlede te herskep of daar te stel of voor te ste $^{26}$ ) was hoofsaaklik dusver die strewe van die historikus. Sy doelstelling bly dus eng maar tog nog noodsaaklik. Daarteenoor bevind die geskiedfilosoof hom wat die daargestelde verskynsel probeer abstraheer en vir hom, die filosoof, tot 'n bevredigende of selfs doelmatige stelsel probeer ombou. Of aan die anderkant kan die filosoof sy denke wend tot die geskiedenis as verskynselprobleem ${ }^{2 \pi}$ ) self en ook die historikus as kreatiewe daarsteller van die verledebeeld en die gedagtewerking van die historikus as menslike kreatiewe en tog op die reste van die verlede bouende wese sien. ${ }^{29}$ ) Sy werksaamheid moet dus noodwendig as abstraksie van die reeds deur die historikus daargestelde gesien word, en omdat hy in die reel oor te weinig vakkennis besit, is hy (die filosoof) ook nie by magte om in te gryp in die tegniese prosesse waardeur die historikus in staat gestel word om die verlede te rekonstrueer of daar te stel nie. ${ }^{30}$ ) Maar aan die anderkant skryf die historikus nie geskiedenis sonder dat hy sy bronnemateriaal

22) Romein, J.: Tussen Vrees en Vrijheid, p. 102.

13) Ibid. p. 103.

21) Vgl. hier Toynbee se Study of History. Hierdie werk rus op die teorie van die beskawingsverskynsels as morfologiese daarstelling. Daarom het Toynbee dus ook volgens Romein se uitgangspunt ,bewys" dat SuidAfrika 'n vreedsame veelrassige of multi-nasionale land soos Switserland is! (Deel IV, p. 293). Sy verkleinerende beskouing van Afrikaans as kultuurtaal (Deel V, pp. 493-4) is reeds bekend. Dit is wonderlik wat mens nie alles buite die werklikheid om uit 'n vooringenome standpunt uit redenerend, kan „,bewys" nie!

25) Die Romeinse historici na die "geboorte van Christus, maak byna geen melding van die Christene as verskynselelement binne hul Ryk nie. Vgl. hier byv.: Joseph Vogt: Das römische Geschichtsdenken und die Anschauung des Tacitus. Uit Grosse Geschichts Denker, pp. 37-56.

26) Op die verskillende aspekte hieromtrent kan ek nie nou hier op ingaan nie daar dit buite die bestek van hierdie werk val. Dat historiologies veel oor hierdie drie vir my afsonderlike begrippe, gesê kan word, is seker.

27) Vgl. hier byv. Karl Jaspers: Vom Ursprung und Ziel der Geschichte. (München).

$\left.{ }^{29}\right)$ Ibid. Ook byv. Meinecke. F.: Die Entstehung des Historisismus, en andere.

30) Romein, J.: Tussen Vrees en Vrijheid, p. 19. 
in verband bring met wat hy sien as "beweegredes" en oorsaaklikheid nie. Laasgenoemdes is alweer konsepsies wat in die gees van die geskiedskrywer bestaan (van weë sy waardebeskouing) en dus buite die struktuur of die historiese reste aanwesig is. ${ }^{31}$ ) Dit word dus 'n metodologiese probleem en word ' $n$ poging om die prosesse wat aanwesig is as modus operandi by die geskiedskrywing as elemente te analiseer. Die uiteindelike daarstelling is dus ' $n$ historiografiese verskynsel. Dit noem Romein dan tereg ook teoretiese geskiedenis.

Tot sover dan die grondslae waarop Romein se geskiedbeskouing rus. Daar is nog baie ander elemente aanwesig en veel kan nog daaroor gesê word, maar vir ons bestek is die hierbo daargestelde genoeg. Dit is verder ook onnodig om hier 'n uitvoerige kritiek oor Romein as historikus en as teoretiese geskiedskrywer te lewer. Dit gaan hier eerder om die historikus Romein soos hy aan ons in SuidAfrika voorgestel is.

\section{„My Meester Romein."}

Veral twee van Romein se leerlinge en navolgers het in SuidAfrika deur hul uitinge opspraak verwek. Hulle is dr. Maria Hugo en dr. F. A. van Jaarsveld.

In 'n kort artikel van haar ${ }^{32}$ ) gee sy 'n kort uiteensetting van hoe sy Romein as historikus sien en begryp. Die eerste indruk wat die leser van die stuk wegdra, is dat dr. Hugo die hoogste agting vir Romein as historikus koester. Sy praat dan ook telkens van hom as "die meester" en erken sy dat syself nog net die weg wat deur haar "meester" aangedui is, ,,aarselend begin betree"..3) So oortuig is sy egter dat Romein se idees soos sy dit verstaan, die tekortkominge van ons historici aan die kaak stel, dat sy in dieselfde asem beweer dat sy nie bevoeg is tot 'n wetenskaplikgefundeerde oordeel oor die werk van Jan Romein nie en dat so 'n poging nie slegs voorbarig (sou) wees nie, dit sou (haar) terselfdertyd medepligtig maak aan die „kwasiewetenskaplikheid" waaraan die geskiedenis in ons jong land (volgens haar) dikwels nog so ernstig mank gaan. ${ }^{31}$ )

Dus, gewapen met die idees van Romein - soos sy dit begryp en selfs erkennende dat sy nog nie bevoeg is tot 'n wetenskaplike oordeel oor sy werk nie, maak sy nogtans 'n kategoriese bewering i.v.m. ons historici, wat getuig van 'n in twyfel ontstane veronderstelling maar wat by haar as sekerheid geprojekteer word. Maar sy gaan verder en na aanleiding van Romein se worsteling met die subjektiewe en die probleem van die verband tussen die nagelate reste waaruit ons as geskiedkundiges die verlede probeer rekonstrueer maar telkens voor die vraagstuk van die "Wertidee" as verbindingsmoontlikheid met

31) Ibid. p. 21.

32) Maria Hugo: Jan Romein. Die Nederlandse Teoretiese Historikus. Uit. : Tydskrif vir Wetenskap en Kuns, April 1951, a.w.

33) Ibid.

31) Ibid. 
alles wat daarmee saamgaan stuit, ${ }^{35}$ ) beweer sy dat die geskiedskrywing veral in ons land saamgeflans is uit sulke geïnterpoleerde beweegredes (kousale verbande voortspruitend uit die subjektiewe Wertidee). ${ }^{36}$ ) Omdat ons ons weerhou het van 'n grondige besinning oor die eise van ons wetenskap en nogtans bewus van die onvermydelike subjektiewe element, het ons historici (uit 'n gevoel van magteloosheid?) die wanindruk as reële gehandhaaf dat objektiwiteit in die geskiedenis deur die geleidelike perfeksionering van ons vaktegniese bekwaamheid gewaarborg is. ${ }^{37}$ ) Geen rekenskap word van die onvermydelike subjektiewe (of simplisties gestel--onvermydelike bevoordeeldheid van die historikus in tyd en plek en omstandigheid vasgevang) gegee nie, met die gevolg dat ons geskiedskrywing bewustelik tendensieus of partydig word. Ons geskiedskrywing kom dus neer op 'n ,naïewe opvatting van dokumenteversameling en feiterangskikking" sonder 'n wetenskaplike besinning oor sy eie historiese werksaamheid en is ons vasgevang in 'n eng nasionale konvensionele historiese betragting. Die rede hiervoor moet volgens dr. Hugo gesoek word in die nasionale en geografiese isolement waarin ons land verkeer. ${ }^{38}$ )

Dr. Hugo veralgemeen dus sonder om haar te kompromiteer deur op besonderhede in te gaan. Die ander skrywer wat ek hier wil noem is dr. F. A. van Jaarsveld. In teenstelling met dr. Hugo het hy nie veralgemeen nie maar direk gewys op die werke van sekere van ons skrywers en soos te verstaan, het dit 'n mate van ,,beroering in ons land" veroorsaak. ${ }^{39}$ )

Soos dr. Hugo en dr. van Jaarsveld ook diep onder die indruk van Romein as ,leermeester" geraak. ${ }^{40}$ ) Aansluitend by dr. Hugo beweer ook hy dat ons ons geskiedenis uit 'n eng in ' $n$ begrensde isolement vasgevange beskouingswyse daarstel. Daardeur veroorsaak ons dat daar tussen tradisie en werklikheid 'n skadelike kloof ontstaan. Ons Afrikaners is besig om ons verlede te sien deur die bril van 'n ,blinde of opsetlike en oormatige romantiese verheerliking". ${ }^{11}$ ) Hierdie sogenaamde vir hom bewustelike bevooroordeelde

35) Sien eerste hoofstuk hiervan.

36) Maria Hugo, a.w.

37) Ibid.

38) Ibid.

39) Die Voorligter, April 1953.

10) Van Jaarsveld, F. A.: Die Politieke Betrekkinge tussen die Suid-Afrikaanse Republiek en die Oranje-Vrystaat. (1836-1899). Deel I. Die Eenheidstrewe van die Republikeinse Afrikaners. (1836-1864). Proefskrif voorgelê aan die Ryksuniversiteit te Groningen. Stelling XI.

11) Stelling XIII. Is die nasies van Europa dan self nie onvermydelik en onoorbrugbaar van mekaar geskei juis uit hoofde van hierdie nasionale tradisie (in die ruimere sin geneem) nie? Tenspyte van onderlinge verkeer, verkeer hierdie Europese nasies nie in 'n absolute isolement nie? Word dit nie weerspieël deur die verskillende geskiedkundige en staatkundige werke nie? Dit is vrae wat eers beantwoord moes gewees het voordat dr. van Jzarsveld so 'n eng bevooroordeelde uit'a'ing i.v.m. toestande in S.A. gemaak het.-Dit sou sy uitlating "wetenskaplike" waarde gegee het. Nou bly dit net ,sensasioneel”. 
siening van ons geskiedenis noem hy die apologetiese element in ons geskiedskrywing. Veral die Transvalers, vasgevang in die gebeurtenisse wat die Transvaalse Republiek tot stand gebring het en daarna gelei het tot die Republiek se ondergang, maak hul skuldig aan hierdie apologetiese of bewus bevooroordeelde siening van ons verlede. ${ }^{4}$ )

$\mathrm{Na}$ hierdie stellingname, vra $\mathrm{dr}$. van Jaarsveld hom dan die vraag af waar hierdie onwetenskaplike en bewus bevooroordeelde siening sy oorsprong het en beweer hy dat dit grootliks teruggevoer kan word op die historiese metode wat dr. W. J. Leyds met sy „De eerste Annexatie van Transvaal" (1906) en „Het insluiten der Boerenrepublieken" (1914) in Suid-Afrika gebring het. ${ }^{34}$ ) Dr. Leyds se metode is eensydig (dus apologeties) en dit moet volgens dr. van Jaarsveld verklaar word in die feit dat $\mathrm{dr}$. Leyds se historiese werksaamheid saamval met ' $n$ periode waarin die Afrikanervolk ook tegelyk gestreef het na selfverdediging van sy bestaan en voortgang op kulturele en politieke gebied. Noodwendig moes hierdie soort geskiedskrywing volgens hom, apologeties, bewus subjektief of eensydig wees. Hierdie vorm van subjektiwiteit sou dan tot vandag toe nie afgeloop wees nie. ${ }^{44}$ )

Die historici na dr. Leyds het ipso facto ook onder die dwang van die tydsomstandighede gestaan; daaruit kon hulle hul eenvoudig nie losmaak nie. As eerste voorbeeld word dan genoem die werk van prof. S. P. Engelbrecht „Geskiedenis van die Nederduits Hervormde Kerk van Afrika" (1920 1925). Die persoon wat veral op die interprestasiewyse van prof. Engelbrecht voortgebou het, was dr. F. A. F. Wichmann (Argiefjaarboek vir S A. Geskiedenis, 1941, deel II). Dit is opgevolg deur die werk van prof. A. N. Pelzer (Wordingsjare, 1950) wat in sy siening en interpretasie van die politieke ontwikkelinge terugval op die "standaard" of ,absolute" interpretasie van prof. Engelbrecht. Hierdie skrywers het veral nie volgens dr. van Jaarsveld, rekening gehou met die faktore van die leierspersoonlikhede, die kerklike groepe, die Engelse en die naturelle in die vorming van die politiske struktuur en die ontplooiing daarvan, ook nie met die eie tradisie en geestelike inhoud van die geografiese politieke groepe wat in 1857 selfs tot vorming van vier aparte republieke oorgegaan het nie. ${ }^{45}$ ) Hierdie apologetiese tendens is volgens $\mathrm{dr}$. van Jaarsveld nie alleen beperk tot die wordingstydperk in ons geskiedenis nie, maar word ook weerspieël in die werk van dr. J. H. Breytenbach oor die Tweede Vryheidsoor$\left.\log { }^{16}\right)$

12) Stelling IV.

(3) Stelling IV.

41) Ibid. p. 5 .

45) Ibid. p. 6

46) Van Jaarsveld, F. A.: Die Eenheidstrewe van die Republikeinse Afrikuners. Deel I: Pioniershartstogte. (1836-1864.) p. 13. (Voortrekkerpers, 1951.) 
Hierdie genoemde skrywers, deur hul eensydige benadrukking van en vooringenomendheid met die subjektiefgeoriënteerde (en dus valse!) heroïse in die begrensde in 'n geografies-geisoleerde Transvaalse maatskappy, word dus deur dr. van Jaarsveld afgehok weg van die historici van byv. die Kaapland, veral byname prof. Thom, en word hulle genoem die volgelinge van Leyds, behorende tot die skool van Engelbrecht ${ }^{47}$ ) of ook die ,.Noordelike skool ${ }^{48}$ )

'n Uitsondering word egter in die geval van dr. G. D. Scholtz van Johannesburg gemaak. Ofskoon dr. Scholtz se magnum opus ook net soos in die geval van dr. Breytenbach gegaan het oor die oorsake van die Tweede Vryheidsoorlog, meen dr. van Jaarsveld tog dat dr. Scholtz nie apologeties gestaan het teenoor sy materiaal nie en dat daar ' $n$ bewustelike strewe tot objektiwiteit in die behandeling van die werk aanwesig is. ${ }^{.9}$ )

Dr. Scholtz en prof. Thom het, nadat dr. van Jaarsveld hul werk buite die kader van die S.A. ,apolegetiese" rigting geplaas het en bewustelik hierdie skrywers buite die ,,apologetiese skool" van die Noorde as toonbeelde van objektiewe skrywers voorgeskilder het. ${ }^{50}$ ) sonder om enigsins ontledend teenoor hul werke te staan, dr. van Jaarsveld se standpunt volmondig ondersteun. Dr. Scholtz sien selfs in die lees van filosofiese werke oor die geskiedenis-as-verskynsel die panacea van die probleem van geskiedskrywing. ${ }^{11}$ ) Hy berus hom by die opspraakwekkende en onverantwoordelike bewering van $\mathrm{dr}$. van Jaarsveld naamlik dat hier aan die Universiteit Pretoria (die geestelike bron van die sg. „Noordelike skool"!) geen poging aangewend word deur die ,oningeligte" here Professore en lektore, van die eise wat die geskiedwetenskap stel nie en dat op die metodologies-filosofiese aspek geen nadruk gelê word nie. Ons doel sou dan wees feitekennis sonder 'n deurdagte en verantwoordelike rasionalisasie van die wetenskap as sulks. ${ }^{52}$ ) Dr. Scholtz, beïnvloed deur dr. v. J., veroordeel byvoorbaat elke werk wat in die kring van die .. Noordelike skool" met sy,

47) Tbid. p. 13.

48) Van Jaarsveld, F. A.: Apologetiek en Objektiwiteit in ons Kerkgeskiedskrywing, p. 6. (1953.)

49) Standpunte, 21.

so) Tbid.

51) Die Transvaler, 12 Maart 1952. Ons kan dr. Scholtz aanraai om hieroor eers die sienswyse van prof. dr. van Winter van die Universiteit van Groningen in te win. Die naam van prof. van Winter word trouens nooit deur dr. van Jaarsveld genoem nie. Dit sou interessant wees om te verneem waarom nie.

52) Standpunte, 21 . Sonder om verder op hierdie bewering in te gaan sou ek hier voorstel dat $d r$. van Jaarsveld hierna 'n deeglike vergelykende studie maak van die werk wat in Pretoria, Stellenbosch en Potchefstroom gedoen word. Hy kan op die volgende ingaan: (a) Die kursusse wat aangebied word vanaf die eerste jaar tot by die doktorale kursus, (b) die metode van lesing gee en (c) reaksie van die studente daarop. 
eng nasionale geïsoleerde interpretasiewyse die lig sien. Onlangs het dr. Jean van der Poel 'n werkie oor die Jameson Ra:d die lig laat sien. ${ }^{53}$ ) In hierdie werk van haar, na die gebruikmaking van sekere gegewens wat onlangs eers toeganklik gemaak is vir die navorser, toon sy ondubbelsinnig aan dat die "Raid" in werklikheid 'n deur Rhodes en Chamberlain geïnspireerde poging tot 'n staatsgreep was met die vooropgestelde doel om die onafhanklikheid van die Transvaalse Republiek te vernietig. ${ }^{54}$ ) Maar ongelukkig het sy die flater begaan (volgens dr. Scholtz) om in haar voorwoord erkenning te gee aan 'n sekere historikus en navorser van die sogenaamde "Noordelike skool" wat sekere dokumente en feite onder haar aandag gebring het. Dit het aan $\mathrm{d} \boldsymbol{r}$. Scholtz (daarna bekroon met die akademieprys vanweë sy werk oor die Tweede Vryheidsoorlog - Ons kom later weer by hierdie werk terug ${ }^{55}$ ) die nodige slaanding verskaf om weereens die "Noordelike skool" aan te val. Hy redeneer asvolg: Omdat die gegewens verstrek is deur persone uit die "Noorde", moet dr. van der Poel se werk onwetenskaplik en dus waardeloos wees. By implikasie word die „Noordelike skool”-stelling van dr. van Jaarsveld. à la Romein, aanvaar. ${ }^{56}$ )

Ongelukkig was die N.H. of G. Kerk toe dr. van Jaarsveld se werk verskyn het, ook gewikkel in 'n pennestryd met die Hervormde kerk oor die geskiedenis van die twee kerke en oor die vraagstuk van die kerknaam..$^{37}$ ) Hierdie pennestryd is hoofsaaklik aan N.H. of G. kerkkant gevoer deur dr. H. S. Pretorius en dit was weldra duidelik dat dr. Pretorius nie opgewasse was vir die taak wat aan hom opgedra is nie. Dr. van Jaarsveld se standpunt nl. dat prof. S. P. Engelbrecht se geskiedenis van die Hervormde Kerk as niks anders as 'n kerkistiese en dus tendensieuse werk beskou moet word nie ${ }^{58}$ ), is onmiddellik deur die N.H. of G. kerk aanvaar en voorgehou as die finale antwoord op die strydvraag van die kerknaam. Die metodologiese standpunt van dr. van Jaarsveld soos hy dit geleer en aanvaar het by Romein, word dus deur hierdie kerk as die korrekte aanvaar. ${ }^{59}$ )

s3) van der Poel, J.: The Jameson Raid. (1951).

54) Ibid.

55) Kyk „Repliek” hieronder.

46) Die Huisgenoot, 15 Febr. 1952 en 24 Maart 1952. Ek wil hier met dr. Scholtz saamstem dat die skryfster die reperkussies wat die inval van Jameson in Transvaal op Europa gehad het in aanmerking moes geneem het. Maar die werk hoef nie noodwendig as onwetenskaplik bestempel te word omdat sy dit nie gedoen het nie. Deur die lig op sekere aspekte te laat val word interessante en tot dusver onopgeloste vraagstukke belig. Die reaksie van Europa kan later behandel word-sonder om noodwendig dr. van der Poel in die ongelyk te stel.

s1) Byv. Die Vaderland, 5 September 1952.

s8) Van Jaarsveld, F. A.: Apologetiek: „Suid-Afrikaanse Kerkgeskiedenis in Swart en Wit".

59) Die Kerkbode, 15 April 1953. Die Voorligter, April 1953. 
Jan Romein het dus via sy leerlinge binne die tydbestek van twee jaar reeds diep spore nagelaat in die gedagtewêreld van ons Afrikaners. Voordat ek tot repliek oor die voorafgaande oorgaan, is dit noodsaaklik om weereens kortliks stil te staan by die vraagstuk van die sogenaamde subjektiwiteit in die geskiedeniswetenskap.

\section{Die Probleem van die Subjektiviteit en die Apologetiek.}

Die probleem van die moontlikheid van absolute onbevooroordeeldheid, onpartydigheid en dus objektiviteit is 'n probleem wat elke twintigste eeuse historikus besig hou. Ongelukkig kan ons nie hier nagaan hoe verskillende denkers en historici sinds die einde van die $19 \mathrm{de}$ eeu en begin 20 ste eeu oor die probleem gedink het nie. Ons moet volstaan deur daarop te wys dat denkers soos Windelband, Rickert, Simmel, Dilthey en Croce die probleem sien as 'n persoonsaangeleentheid of vraagstuk. Die individu, deur sy opvoeding, sosiale agtergrond en gebondenheid aan tradisie, moet noodwendig wanneer hy ' $n$ vraagstuk aanpak, die vraagstuk sien in terme van homself. Soos Romein dit stel: Die wetenskap met sy wette bestaan nie buite en onafhanklik tenspyte van die mens nie maar die mens soek en vind wetmatighede binne die natuur wat vir hom vir sy tyd 'n bevredigende verklaring gee van die wêreld waarin hy hom bevind. ${ }^{60}$ ) Die $18 \mathrm{de}$ en $19 \mathrm{de}$ eeuse mens met sy besondere siening van die wêreldstruktuur, sou nie Einstein se relativiteitsbeginsl kon ontwikkel nie. Dit moes oorgelaat word aan die 20 ste eeuse positivis.

Ook elke tydperk of periode het sy besondere waardeoordeel oor die verlede. Die historikus is dus onvermydelik subjektief en interpreteer die verlede uit die hede (volgens Romein). Hy dwing met ander woorde die verledebeeld om sy hede te regverdig. Romein aanvaar dus die subjektiwiteit en wil terselfdertyd die subjektiwiteit as werksame element in die geskiedskrywing verhef tot objek van studie. ${ }^{61}$ ) Die werk wat so gelewer word is dus tiperend vir die besondere tydsgees en omstandighede waarin dit geskryf is. Hierdie historiografiese werk kan dus tot bron van studie gemaak word ${ }^{62}$ ) Dus moet die geskiedenisuiting van 'n historikus soos byvoorbeeld sy beskouing van die onvermydelike verval (by Polybius byv.) van die Romeinse Ryk, slegs saamhang met die geskiedenis van daardie historikus se eie tyd. ${ }^{63}$ So ook is Gibbon, Rousseau en Montesquieu se siening en interpretasie van sekere aspekte van die Romeinse Ryk beinvloed deur die tydsgewrig waarin hulle gelewe het.

60) Vgl. Eerste onderhoofstuk: Die grondslae van Romein se teoretiese denke.

61) Maria Hugo, a.w.

62) Sien eerste onderhoofstuk en Maria Hugo, a.w.

63) Romein: Het Onvoltooid Verleden, p. 112, a.w. 
Dus, of ons dit nou wil ontken of nie, lei bogemelde siening van dinge en veral aanvaarding daarvan deur die geskiedkundige tot twyfel i.v.m. die geskiedenis-as-wetenskap. Ook terselfdertyd laat dit twyfel ontstaan by die mens oor die moontlikheid van 'n absolute waarde (soos die godsdiens) waaraan hy kan glo. Dit lei tot onvermydelike skeptisisme en selfs tot die aanvaarding van geen waarde nie. Maar nihilisme (geloof in niks) is, of veronderstel outomaties weer die glo in 'n waarde (in hierdie geval die beginsel van "niks" as waarde.) Wat ons op die grens laat beland van die filosofiese rigting bekend as die eksistensialisme.

Hier moet die sogenaamde waardefilosowe outomaties in 'n sirkel begin dink. Dit het Romein ook besef en besef hy dus dat hy as mens, om sekerheid vir homself binne die lewe te verseker, 'n keuse moet doen van die waardes van sy tyd. Hy kies die Marxistiese sosialisme. ${ }^{64}$ )

Deur hierdie vorm van subjektivisme te aanvaar, beweeg die historikus dus op die grense "tussen iets en niks". ${ }^{65}$ ) Die historikus word, uit hoofde van die konsekwensies wat hierdie denkrigting inhou, tot twyfel gebring.

Hierdie moontlikheid het die Engelse denker Collingwood ook ingesien. ${ }^{66}$ ) Die uitweg hier, word asvolg gesien: Wanneer die historikus die geskiedenis van die Jode en die vroeë Christendom probeer daarstel sal hy as wetenskaplike historikus nie die mense se geloof in wonderwerke sondermeer gaan interpreteer as "bygeloof" nie. Vir hulle is die werklikheid 'n ander werklikheid gewees, vir hulle het die wonderwerke wel in werklikheid plaasgevind ${ }^{67}$ ) Wanneer die moderne Roomskatoliek tydens sekere godsdienstige feeste glo dat ' $n$ flessie water in bloed verander, dan moet die historikus of hy Roomskatoliekgesind is of nie, die feit aanvaar dat dié flessie water wel in bloed verander het sover as wat dit daardie groep Roomskatolieke betref. $\mathrm{Om}$ ' $\mathrm{n}$ voorbeeld te neem wat nader aan ons is: Wanneer in die vyftiger jare van die vorige eeu 'n sekere Xhosameidjie beweer het dat die Xhosa-voorvadere die Xhosas beveel het om al hul beeste te slag en kosvoorrade te vernietig waarna die voorvadere sal ingryp en die blankes uit die land verdryf, dan kan ons dit nie

6.) Romein, Jan : Het Onvoltooid Verleden, p. 87, a.w.

65) Lees die prikkelende klein werkie van Dr. Meyer: „Tussen Iets en Niks.” (1952).

it) Collingwood, R. G.: The Idea of History, pp. 205-321. (Oxford, 1948).

Die werklikheid soos deur bepaalde groepe binne die tydsverloop gesien, is dus aan veranciering onderhewig. Uit die werkiikheid word die waardebeginsel geabstraheer. Waardebeginsels soos voorkomend binne die tydsverloop kan dus as objek van studie gemaak word. Waaruit voortvloei dat die waardebeginsel as objektiewe buite die historikus bestaande verskynsel, daargestel kan word. (Anders sou die studie van byv. die

67) Ibid. volkekunde onmoontlik gewees het). 
uit hoofde van ons blankes se twintigste eeuse lewensbeskouing sondermeer verwerp as die ydele droom van 'n gefrustreerde meidjie nie. As die stamkaptein die sendeling in sy kraal vermoor of uitdryf mag die historikus al is hy 'n Christen, die optrede van die kaptein nie sondermeer beskryf as in heiden se onverantwoordelike optrede teen die sendeling nie. Wanneer in studie gemaak word van die stamlewe van die naturel word daar algou besef dat die uitdrywing van die sendeling ' $n$ beskermende maatreël is om te verhoed dat sy stam as eenheidsgroep uitmekaar val. ${ }^{68}$ ) En hierdie interpretasie word verkry tenspyte van die feit dat die historikus 'n Christen is. Dus tenspyte van die vooringenome waardebeginsel van die historikus.

Dit word dus duidelik dat die historikus, as wetenskaplike, nie absoluut gebind word deur die hedewaardes in sy interpretasie van die verlede nie. Dat daar 'n element van die hedewaarde steeds aanwesig sal wees, gee ek geredelik toe maar die wetenskaplike historikus. deur gebruikmaking van sy tegniek - bronneversameling ens. in sy doelbewuste eerlike strewe na die waarheid, is in staat om die kousale verband tussen dinge te sien wat buite sy waardegebied lê. Wanneer dr. G. D. Scholtz die oorsake van die Tweede Vryheidsoorlog behande ${ }^{69}$ ) sien hy nie die Jamesoninval of Rhodes se optrede as ten dele heilsaamwerkend nie. Die uitbreek van die Tweede Vryheidscorlog moet noodwendig gesien word as 'n katastrofe vir die Republiek. Maar as die skrywer die Tweede Vryheidsoorlog en alles wat daarmee saamhang sien uit die hede en dit daarvolgens interpreteer, dan was die Vryheidsoorlog geen katastrofe nie! - Theodor Litt het ook reeds op die gevaar van hierdie hede-tot-die-verlede interpretasie gewys. So 'n tipe werk besit niks anders as propagandawaarde nie en is subjektief of apologeties. ${ }^{70}$ ) As voorbeeld van hierdie tipe historikus in Suid-Afrika kan ons neem dr. Keppel Jones van die Witwatersrandse Universiteit. ${ }^{11}$ ) Waarom hy ons geskiedenis so interpreteer is om klaarblyklike redes duidelik.

Ek stel dit dus kategories, in teenstelling met Romein, dat die historikus wat homself enigsins vergewis het van die eise wat sy wetenskap aan hom stel, sy interpretasie van die verlede gedeeltelik buite sy waardebeginsel om kan doen. Hierdie hoofstuk kan ons dus hier afsluit deur te volstaan met 'n aanhaling uit die werk van prof. $\mathrm{Geyl}^{7^{2}}$ ) t.o.v. die sogenaamde wertidee van Romein as in die geskie-

68) Sien my werk: Die verhoudinge tussen die Boere, Engelse en Naturelle in die Geskiedenis van die Oos-Transvaal tot 1882. (Argiefjaarboek, 1951, deel I).

$\left.{ }^{69}\right)$ G. D. Scholtz: Die Oorsake van die Tweede Vryheidsoorlog, twee bande, 1951.

${ }^{30)}$ Theodor Litt: Wege und Irrwege Geschichtlichen Denkens. (Münch $€$ n. 1947.)

71) Keppel-Jones: South Africa. (1952).

72) Geyl, Prof. Dr. P.: Tochten en Toernooien, p. 160. (Utrecht 1950.) 
denis deurwerkende krag: „En zo meen ik dat het roekeloos gebruik van het begrip tijdgeest, de simplistische onderscheiding in ware en valse tijdgeest, het willen afmeten van iedere geschiedschrijver naar zijn verhouding tot de tijdgeest - ik meen dat heel dit schermen met een inderdaad zo vaag begrip door-en-door onhistorisch moet heten. Als Romein het niet bij een algemene beschouwing liet, maar dit in bizonderheden ging toepassen, zou hij tot uitkomsten geraken die zich met zijn reddende zekerheidstheorie al heel slecht zouden verdragen".

Ons kan nou daartoe oorgaan om repliek te lewer op dr. Maria Hugo en dr. F. A. van Jaarsveld se sogenaamde geskiedbeskouing soos uiteengesit in onderhoofstukkie twee .My Meester Romein" hierbo.

\section{RePliek.}

Dit is opvallend dat dr. van Jaarsveld en dr. Hugo, ofskoon hulle sterk onder die invloed van Romein staan en veral laasgenoemde deurdrenk is met sy stellinge, daar nêrens deur hierdie twee persone melding gemaak word van die feit dat Romein 'n Marxistiese sosialis is nie. Dit is wel waar dat dr. Maria Hugo daarop wys dat Romein se teoretiese geskiedbeskouing berus op die dialektiese beginsel ${ }^{73}$ ) maar sy verswyg die feit dat Romein die volle konsekwensies getrek het uit hierdie beginsel. Dit geld ook vir dr. van Jaarsveld. Hy het selfs tot dusver nêrens 'n poging aangewend om die grondslae van Romein se denke na te gaan nie. Met ander woorde, hy het eenvoudig aanvaar sonder om homself te vergewis van die konsekwensies of grondslae van dit wat hy aanvaar het.

In die betrokke artikel van haar gee sy die indruk asof Romein se teoretiese beginsel voortspruit uit sy besinning oor die geskiedenis as onderwerp van besinning en deur ,"'n wetenskaplike besinning oor sy eie historiese werksaamheid (sal hy) tot 'n hoëre dialektiese-denke ontwikkel'. ${ }^{74}$ ). In werklikheid het hy die Hegelse dialektiek aanvaar en op die geskiedenisverskynsel as kennisprobleem gaan projekteer ten spyte van die feit dat hy juis die geskiedfilosofie as te geabstaheerd bokant die geskiedenis as werklikheid gesien het en daardeur tot sy idee van 'n teoretiese geskiedenis gekom het.-Daarin berus Romein se onoorspronklikheid as denker en dit is juis daar waar dr. Maria Hugo en dr. van Jaarseld buite die grondslae van sy denke om, sy uitsprake aanvaar het. Dat hierdie twee Afrikaanse skrywers uit onkunde die feit verswyg het dat Romein 'n Marxistiese sosialis is, kan moeilik aanvaar word daar hulle tog gedurig in aanraking is met hul "leermeester" se werke. Ek wil hier aanneem dat hierdie feit verswyg

73) Maria Hugo, a.w. En dit ook sonder om die feit te benadruk.

74) Ibld. 
is of omdat daar onbewus gevrees is vir die reperkussies wat dit in 'n antikommunistiese land soos Suid-Afrika sou hê, of omdat hulle tot dusver so vasgevang is deur en so onder die indruk van Romein se persoonlikheid en sy gedagtes is soos weergegee in sommige van sy selfs skitterende essays, dat hulle tot dusver nog nie in staat was om hulself los te maak van hom en sy stellinge as intellektuele probleem kon sien nie. Aangesien veral $\mathrm{dr}$. Hugo nog steeds besig is met Romein as teoretiese historikus ${ }^{75}$ ) sal ons seker eersdaags 'n artikel oor Romein as sosialistiese denker uit haar pen sien. - Dit sal verwelkom word aangesien baie vrae aangaande die figuur Romein daardeur miskien opgelos sal word.

Dr. Maria Hugo maak verder die bewering dat ons historici ",kwasie-wetenskaplik" is omdat ons ten eerste ons geskiedenis interpreteer uit ' $n$ té eng in 'n isolement vasgevange nasionale beskouingswyse. Ons wil met ander woorde die volkstryd van die hede (soos ons dit aanvoel) projekteer op die verlede. Maar dit is juis wat Romein as onvermydelik beskou en het Romein self juis sy Hegelse dialektiek op sy teoretiese geskiedbeskouing gaan projekteer. ${ }^{76}$ ) Word dit nie hier die ou beeld van die splinter en die balk nie, of is dit die resultaat van die onbewustelike drang tot sensasie? Haar standpunt wat hieruit voortvloei naamlik dat ons historici dus geen rekenskap gee van hierdie onvermydelike subjektiewe element nie, kom uit hoofde van voorgaande dus ook verdag voor. Dat daar wel historici is wat dit nie doen nie is ' $n$ stelling wat van toepassing is op historici van ook Amerika, Holland, Frankryk, Engeland, ens. Haar verwerping van die Afrikaanse historikus is derhalwe té onverantwoordelik kategories eng gestel. Soos sy dit stel is ons in ons sogenaamde geografies-bepaalde in isolement vasgevange klompie historici 'n "einmalige" verskynsel binne die res van die wêreld. Sy het haar m.a.w. nie behoorlik vergewis van wat ander lande wat ons werke lees daaroor te sê het nie. Dit is hierdie tipe eng uitinge wat ons ook by Romein aantref wat 'n bekende Nederlandse historikus soos prof. dr. Geyl gedwing het om na die pen te gryp en in besonder skerp taal Romein en sy "leerlinge" te lyf gegaan het. ${ }^{i 7}$ ) $\mathrm{Hy}$ was eenvoudig verplig om sy vakgenoot tot verantwoording te roep.

75) Ibid. Juis in die feit dat Romein die Marxistiese sosialisme as waardebeginsel aanvaar hou hierdie aanvaarding ook prinsipieel die idee in dat die indiwidu nie onwillekeurig vasgevang word deur 'n waardebeginsel nie maar dat dit 'n bewuste kendaad is. Die beslissingsoomblik plaas die beslisser ook buite die aanwesige waardebeginsels om daarna weer deur die aangenome beginsel oorheers of beheers te word. Gevolglik hou dit die erkenning van die moontlikheid van objektiwiteit in. Waardeur Romein hom dan ook self weerspreek. (Hier land ons weer naby Lord Acton se idee oor die probleem. Ongelukkig was dit buite ons bestek om die probleem van die moontlikheid van objektiwiteit te behandel. Vgl. in elk geval Acton se "History of Freedom and Other Essays"-1922-hiermee.)

76) Lees onderhoofstukke 1 en 2 ,Jan Romein" en "My Meester Romein."

77) Geyl, Prof. Dr. P.: Tochten en Toernooien, pp. 154-165 en 166-214. 
Hierdie selfde eng kategoriese uiting vind ons ook by dr. van Jaarsveld ${ }^{78}$ ) Vir hom geld dieselfde opmerking as hierbo gemaak. Daardeur wil ek nie beweer dat ons uitstaande historici van wêreldformaat reeds voortgebring het nie, want daarvoor is ons wetenskapsbeoefening hier te lande nog te jonk en is dit die rede waarom op byna geen ander gebied 'n Einstein, Toynbee, Hegel of Pasteur, as u wil, na vore gekom het nie. Dit is veral vir die filosoof fataal om vanuit 'n perfeksionistiese standpunt uit te wil redeneer. Sy siening van die dinge buite hom sal tè veel in wit en swart afgeteken staan. D.t is ook waarom dr. van Jaarsveld die historici i $~ o n s$ land afkamp in 'n sogenaamde "Noordelike skool" en die groep buite hierdie „skool" van die noorde. Die "Noordelikes" word swart gesien - eng, geïsoleerd, onverantwoordelik, kerkisties, subjektief-apologeties, ens. en die groep daarbuite as diè historici wat voldoen aan die eise van die wetenskap. ${ }^{79}$ ) Daardeur hou hy homself natuurlik ook voor as een van die perfektes.

Soos ons ook gesien het beweer dr. van Jaarsveld dat die Afrikaner se romantiese verheerliking van die verlede die gevaar laat onstaan dat tussen tradisie en werklikheid 'n gevaarlike kloof sal ontstaan. ${ }^{80}$ ) As dr. van Jaarsveld met "werklikheid" bedoel geskiedenis-as-werklikheid, dan kom dit voor asof hy, tenspyte van sy teoretiese geskiedbepeinsinge, nie volledig ingegaan het op die konsepsie van die idee tradisie en werklikheid nie. Tradisie is dit waaruit die hedemens ,die nie-historikus", die mens vasgevang binne die kader van sy groep - veral nasiegroep - sy waardestellinge neem om sy toekoms mee te probeer destineer - of bepaal. Die mens lewe tot die toekoms maar dit is "n toekoms wat hy doelbewus uit die Wertidee van die hede wil bepaal. Sy verlede soos hy dit uit die hede sien, dus as nie-historiese werklikheid - vorm die sekerheid van die voortbestaan van die hedegroep. Ons kom dus weer terug by Romein naamlik dat die hede die basis vorm om die verlede te interpreteer, kousale verbande tussen dinge te sien en na waarde te bepaal. - Hoeveel mense glo nie vandag nog dat Genl. Beyers doelbewus in die Vaalrivier vermoor is nie, hoeveel mense kleef nie vandag nog vas aan die idee dat die moord op Retief beplan is deur die sendelinge nie? - Dit is tradisie en of ons dit nou wil aanvaar of nie, 'n nasie bou sy toekoms daarop. Ons het ons konsentrasiekampe, die Jode het hul konsentrasiekampe in Duitsland, die Duitsers het hul Leipzig en Jena, en die Engelse hul Waterloo. Tradisie is veel meer as ' $n$ abstrakte konsepsie, dit is 'n absolute

78) Sien onderhoofstukke 1 en 2 soos hierbo genoem.

$\left.{ }^{79}\right)$ Standpunte 21, Eenheidstrewe en Apologetiek in ons Kerkgeskiedskrywing.-a.w.e.

so) Stelling XIII. 
werklikheid, 'n absolute waarde - dit word geloof. Vandaar die feit dat die Jode selfs na eeue van verstrooiing nog kan terugkeer na Israel en ofskoon rassesegregasie soos dit vandag in Suid-Afrika gepropageer word, as 'n wetenskaplike onbewysbare onding, as ' $n$ mite beskou word ${ }^{81}$ ) nogtans is hierdie ,"mite" 'n absolute werklikheid vir die twintigste eeuse Afrikaner. Die Brit glo dat dit alleenlik die Britse soldaat was wat Napoleon by Waterloo verslaan het. Dit is sy tradisie, dis wat die geloof by hom verwek dat in die oorloë wat kom, daar weer Waterloos sal wees. - Vergelyk maar Churchill se geloof gedurende die afgelope oorlog dat Brittanje veldslae kan verloor omdat die finale en beslissende slag gewen sal word! Dit is deur die tradisie wat die hedemens van homself verantwoording doen vir die toekoms.

Die historikus vernietig soms hierdie tradisie omdat hy die historiese werklikheid wil benader. Die slag van Waterloo is vir hom eers gewen nadat die Pruisiese leër onder Blücher opgedaag het. Ook is die historikus ten dele daartoe in staat om die wording van die tradisie na te gaan. Ons is in staat om, na aanleiding van die verledereste, by benadering aan te toon hoe die idee van segregasie ontstaan het en hoedat dit uitgeleef is deur die blanke bewoners van die Republieke. Daarby hou tradisie egter ook 'n element van waarheid in. Beyers het in die Vaalrivier omgekom, die Duitsers is in die slag van Jena deur Napoleon verneder en die Britte het in die slag van Waterloo teen Napoleon geveg. Dit is dus juis hierdie romantiese verheerliking van die verlede wat 'n brug slaan tussen tradisie en werklikheid. Die eindpunt van tradisie in die hede is in der waarheid absolute werklikheid. Dit is nie wetenskaplik bepaalbaar nie, dit is geloof ${ }^{82}$ ) Soos ons reeds gesê het is dit juis onwetenskaplik vir die historikus om die nasiegroep se waardeidee te verwerp uit hoofde van sy rasionalisasie daarvan as verskynsel. Hy moet dit bepaal, daarna aanvaar en dit gebruik om die kousale verband tussen dinge te sien. (En dit ten spyte van die feit dat hy waarskynlik 'n waardebeginsel daarop nahou wat heeltemal daarmee verskil).

Hier is dr. G. D. Scholtz op die regte spoor wanneer hy die werk van die Hollander A. Kaptein oor Suid-Afrika bespreek en beweer dat Kaptein objektief oor Suid-Afrika skryf. Kaptein het ,eers in studie gemaak van die land alvorens hy die pen opgeneem het" ${ }^{83}$ ) Dit is net jammer dat dr. Scholtz somtyds tè maklik die woordjies objektief en subjektief gebruik om sy persoonlike standpunt te regverdig. ${ }^{84}$ )

81) Marais, Dr. Ben J.: Die Kleurvraagstuk en die Weste, pp. 14-70 : „Moord op die Mites". (Goeie Hoop Uitgewers, 1952).

82) Vgl. ook hier die Hindoe en sy godsdiens. Die westerling vind dit belaglik dat die Hindoe die koei en bobbejaan as "heilig" beskou.

s3) Die Transvaler, 29 April 1953.

84) Die Huisgenoot, 15 Febr. 1952 en 28 Maart 1952. 
Dr. W. J. Leyds word beskou as die sogenaamde grondlegger van die "Noordelike skool". ${ }^{85}$ ) Sy ",metode" word beskryf as eensydig uit hoofde van die feit dat hy dan kwansuis as verdediger van die gewese Republiek optree. Dus is sy "De Eerste Annexatie" en "Het Insluiten van de Boeren-Republieken" 'n apologetiese nie-wetenskaplike werk. ${ }^{86}$ ) Van die veronderstelling word uitgegaan dat $\mathrm{dr}$. Leyds bewustelik 'n waardeoordeel geprojekteer het op sy materiaal om daardeur die historiese beeld volgens uit die hede-wertidee daar te stel. Dit beteken m.a.w. ' $n$ verdraaiing van die historiese werklikheid. Dit het veral gedurende die afgelope wêreldoorlog mode gewerd om historici wat hul eie nasionale verlede beskryf of probeer daarstel het, as apologete te bestempel. Die bekende Italiaanse denker Croce het. uitgaande van dieselfde beginsel, die brroemde historikus Leopeld von Ranke aangeval omdat hy dan té veel die Duitse geskiedenis benadruk het. Hy word ook deur Croce as apologeet bestempel. ${ }^{87}$ ) So ook word prof. S. P. Engelbrecht se geskiedenis van die Hervormde Kerk deur $d r$. van Jaarsveld as ' $n$ apologetiese en dus waardelose werk bestempel omdat dit dan kerkisties is. ${ }^{8}$ ) Prof. A. N. Pelzer, dr. J. H. Breytenbach, Eric Walker (sic!) ea. word as volgelinge van prof. S. P. Engelbrecht bestempel en sou hulle dus tot die sogenaamde "Noordelike skool" behoort. ${ }^{89}$ )

Wat dr. van Jaarsveld se aanval of verwerping van dr. Layds as historiograaf betref, net die volgende: Nadat dr. Leyds se, De Eerste Annexatie" in 1906 verskyn het, het die volgende kommentaar in Engelse tydskrifte verskyn: "If all these facts had been before the British people in 1899 there could have been no war," . . . ."1) "Dr. Leyds is able to show that twice over, as a result of the twofold operation of British influence, local and imperial, Britain has committed the greatest wrongs". . . ${ }^{91}$ ) terwyl in die "The Athenaeum" in die uitgawe van 1 September 1920 na die verskyning van $d r$. Leyds se ".Het Insluiten van de Boeren-Republieken", 'n vergelyking gemaak word tussen dr. Theal en dr. Leyds as geskiedskrywers: .A comparison immediately reveals the defects of Dr. Theal. Many people believe that the first duty of an historian is to be impartial, but that is a delusion; the first duty of a historian is to be a historian. Unfortunately the late Dr. Theal, though he wrote a history in eleven volumes, was no historian. He was an annalist, which is something

\footnotetext{
85) Van Jaarsveld, p. 13, a.w.

86) Tbid.

87) Croce: History as the story of Liberty. (London, 1941.)

88) Van Jaarsveld: A pologetiek, pp. 6-40, a.w.

89) Ibid., p. 6.

90) The Tribune, 10 September 1906.

91) The Speaker, 10 September 1906.
} 
entirely different. ... All through his work matters of high politics are sandwiched between items of information such as are found in small print in the Littlehampton local paper, and when reading about events which made and destroyed empires, we always expect to turn the next page and learn that at X on the evening of Sunday "March", 1881 , a calf was born with two heads .... Dr. Leyds gives you the material for understanding the significance of the events dealt with by him. You look back, and in the light of history Majuba and the dynamite explosion, economic imperialism and the flooded gardens of Heidelberg, fall into their proper places and assume their right proportions in the sight of God. But Dr. Theal looks at history with the eye not of God, but of the editor of a local paper, and the reader is left with no understanding of the great tides which swept white and black humanity this way and that in South Africa, but with a confused vision of a welter of unmeaning facts." ${ }^{33}$ )

Wanneer dr. G. D. Scholtz se werk: „Die Oorsake van die Tweede Vryheidsoorlog" met die reeds genoemde werke van dr. Leyds vergelyk word, veral die eerste deel van dr. Scholtz se werk waarin bykans dieselfde veld as dr. Leyds s'n gedek word, dan is dit opvallend dat afgesien van die verskil in styl en stofindeling, die konklusies wat bereik word hoofsaaklik ooreenkom. Daarby is dit verder ook opvallend dat die tweede band van dr. Scholtz se werk waarin die gebeurtenisse behandel word wat onmiddellik aanleiding gee tot die uitbreek van die Tweede Vryheidsoorlog, weer ooreenkoms toon, wat die algemene konklusies betref, met die werk van dr. J. $H$. Breytenbach oor dieselfde onderwerp. Dr. van Jaarsveld aanvaar dr. Scholtz as een van ons uitstaande historici - en dit heeltemal tereg ook - maar verwerp die ander genoemde historici as bevooroordeelde apologete vir die Boere-saak. Daar moet hier weereens met klem gestel word dat genoemde historici - Drs. Scholtz, Leyds en Breytenbach - 'n nie-Romeinse siening van die geskiedskrywing daarop nahou. Dr. van Jaarsveld was nie hier konsekwent nie.

As ons verder die maatstaf waarmee dr. van Jaarsveld die werk van $\mathrm{dr}$. Leyds en prof. Engelbrecht meet gebruik en dit toepas as wetenskaplike beginsel om prof. H. B. Thom se werk oor die lewe van Gert Maritz te beoordeel, ${ }^{94}$ ) dan moet ook hierdie werk as 'n apologetiese werk verwerp word ${ }^{95}$ ) en dit ten spyte van die feit dat dr. van Jaarsveld prof. Thom se werk buite dit kader van die sogenaamde "Noordelike skool" plaas. ${ }^{96}$ ) Dr. van Jaarsveld gebruik hier meet as een maatstaf waarvolgens hy die Afrikaanse historici na aan-

93) The Anthenaeum, 10 September 1920-Citato.

9.) Thom, Prof, H. B.: Die Lewe van Gert Maritz. (Nasionale Pers, 1947.)

95) Ibid. Lees veral die volgende hoofstukke: (i) oor die oorsake van die Groot Trek, (ii) Die trekgedagte en geheime voorbereiding, (iii) Die Eerste Voortrekkerbestuur en (iv) Wrywing tussen Maritz en Potgieter.

\%r) Standpunte, 21. 
leiding van hul werk meet. Dit kom my jammer genoeg, as niks anders as ' $n$ vorm van opportunisme voor nie.

Dit is verder ook duidelik dat prof. Thom en dr. Scholtz hier voor 'n onverbiddelike keuse gestel word. Aanvaar hulle Romein à la dr. van Jaarsveld, se standpunt, sal hul keuse finaal wees en moet daar noodwendig ' $n$ reoriëntasie by hulle plaasvind wat betref die metode van hul geskiedskrywing en ipso facto ook hul siening van die verlede.

Voorheen het ek reeds daarop gewys dat as dr. van Jaarsveld se verskillende uitinge in sy geheel geneem word en in verband met mekaar gebring word, sy kritiek as niks anders as subjektief gekleurd en dus suiwer apologeties is nie. ${ }^{97}$ ) $\mathrm{Na}$ aanleiding van die voorafgaande is dit dus weereens duidelik. Jammer genoeg is $\mathrm{dr}$. Scholtz genoeg beïnvloed deur $\mathrm{dr}$, van Jaarsveld om dieselfde neiging tot opportunisties apologetiekgeneigde kritiek te lewer. ${ }^{98}$ ) Prof. A. N. Pelzer word as behorende tot die "Noordelike skool" en dus as onwetenskaplik en verwerplik bestempel, terwyl aan die anderkant prof. Pelzer se werk deur die bekende Nederlandse kritikus W. Coolhaas voorgehou is as 'n voorbeeld van wetenskaplike geskiedskrywing. ${ }^{99}$ ) Ons moet dus noodwendig ook skepties staan uit hoofde van voorafgaande, teenoor $d r$. van Jaarsveld se heftige en bevooroordeelde kritiek op die werk van prof.S. P. Engelbrecht.

Dat daar wel sekere aantoonbare leemtes en tekortkominge in die werk van prof. Engelbrecht bestaan, wil ek geredelik toegee, nie omdat die werk in sy geheel daardeur vernietig word en as onwetenskaplik bestempel mag word nie, maar omdat dit menslik gesproke bykans onmoontlik is om die volmaakte te bereik. So is enige historikus ook in staat om na aanleiding van die werk van enige groot historikus sok tekortkominge aan te toon. Macaulay, Greene, Prescot, Ranke, Toynbee, Buckle ens. het trouens nie hieraan ontsnap nie. Die eis word egter aan die kritikus gestel om darem as wetenskaplike, verantwoordelik te staan teenoor die werk wat hy behandel. Besadigheid en strewe na objektiwiteit is hier 'n voorvereiste.

Daar is reeds voorheen daarop gewys hoedat dr. van Jaarsveld self nie kan ontvlug aan die subjektiwiteit in sy werk wat hy aan ander toegedig het nie. Paul Kruger word bewustelik langs die figuur

97) Die Hervormer, Maart 1953.

98) Vgl. sy resensie van die werk van dr. Jean van der Poel. Stel daarnaas die resensie oor dieselfde werk soos dit verskyn het in „The American Historical Review, vol. LVIII, No. 2, van January 1953. Dr. Scholtz is heftig uit 'n vooringenome standpunt uit verdoemend, terwyl die Amerikaner analities, objektief staan teenoor die werk. Dr. Scholtz wil elke werk aan sy eie beginsels laat beantwoord - beginsels wat hy self nog nie geformuleer het nie maar tipeer as „wetenskaplik", terwyl die Amerikaner juis probeer om sy beginsels nie "as 'n maatstaf te gebruik nie.

99) Tijdschrift voor Geschiedenis. Aflewering 1-2, 1952. 
van M. W. Pretorius en Schoeman gestel; die maatstaf wat gebruik word om vas te stel of Pretorius en Schoeman kleinlik en onverantwoordelik optree word gemeet volgens die optrede van Paul Kruger asof hierdie grootse figuur uit ons verlede nie ook soms as mens foute kon begaan nie! Sy bewustelike gebruikmaking van die in Europa ontstane wetenskaplike teorie van die invloed van die geografie op die maatskappy en die wyse waarop hy sy daargestelde historiese beeld dwing om by hierdie teorie in te pas, is reeds bekend. ${ }^{100}$ Dit maak sy aanvalle op dr. S. P. Engelbrecht en prof. A. N. Pelzer uit hoofde van hierdie verkeerde standpunt, des te meer onverantwoordelik.

Hoër op het ek reeds daarop gewys dat Romein se siening van dinge en die beginsels waarop sy teoretiese geskiedskrywing berus, onvermydelik tot 'n vorm van relativisme, d.i die veronderstelling dat geen waarde absoluut is nie en dat m.a.w. die beginsels waarop ons kerke hul voortbestaan regverdig, veranderlik en dus nie ewig is nie, moet lei. Die gevaar wat hierdie denkbeeld vir ons Christelike kerke inhou, is vanselfsprekend. Die reeds bekende prof. Bavinck het dan ook reeds ernstig gewaarsku teen die relativisme as beginsel. ${ }^{101}$ ) Aangesien sekere kerkhistorici van die N.H. of G. Kerk die kritiese beginsels van $\mathrm{dr}$. van Jaarsveld aanvaar ${ }^{102}$ ) om dit te gebruik in hul aanvalle op die Hervormde Kerk, word ook hulle hier voor 'n onverbiddelike keuse gestel. Al dadelik wil ek erken dat dit voorkom asof die betrokke kerkhistorici nie 'n besef het van die werklike gevaar wat daar skuil in die aanvaarding, miskien selfs gedeeltelik, van die beginsels van Romein nie. Nou weet hulle dit in elk geval.

Ten slotte sou ek voorstel, na aanleiding van die polemiek oor die oorsprong van die Kerknaam, ja selfs ernstig daarop aandring dat in die vervolg wanneer deur hierdie kerkhistorici uit-

latings gemaak word van in historiese aard, hulle eers met die geskiedenisdepartemente van die verskillende universiteite skakel. Baie misverstand en selfs vooroordeel sal daardeur uitgeskakel word en die gevolgtrekking sal in die meeste gevalle meer gesag dra.

\section{T. S. VAN ROOYEN.}

100) Die Hervormer, Maart 1953 en Hervormde Teologiese Studies, Mei 1952. Dr. van Jaarsveld se doelbewuste strewe om "helde" te verguis herinner my aan die oppervlakkige werkie van E. Gladys-Thoughts of a Fool (1905)—p.p. 29-38.

101) Bavinck, dr. J. H. : Persoonlijkheid en Wereldbeschouwing. (1928). Veral word die leser aangeraai om sy aandag te skenk aan die eerste hoofstuk: „De Strijd om een wereldbeschouwing", pp. 5-24. "Het relativisme is een doodelijk gevaar voor elk ernstig en deugelijk worstelen om waarheid en recht" (pp. 11-12).

102) Die Voorligter, April 1953 en Die Kerkbode, 15 April 1953. 